\title{
Comparison of the effectiveness of integrative couple therapy and integrative behavioral couple therapy on increasing the resilience of couples affected by infidelity
}

\author{
Hajar Salari Feizabad ${ }^{1}$, Rahmatollah Nouranipoor ${ }^{2}$, Kianoosh Zahrakar ${ }^{3}$ \\ 1- PhD Student in Counseling, Department of Counseling, Science and Research Branch, Islamic Azad University, \\ Tehran, Iran. \\ 2- Associate Professor, Counseling Department, Shahid Beheshti University, Tehran, Iran (Corresponding Author). \\ E-mail: rnoorani41@gmail.com \\ 3- Associate Professor, Department of Counseling, Kharazmi University, Tehran, Iran.
}

Received: 04/11/2020 Accepted: 18/01/2021

\begin{abstract}
Introduction: Marital infidelity is the most harmful act in a relationship, destroys the trust of the injured spouse, it reduces resilience and has unfortunate consequences.

Aim: The aim of this study was to compare the effectiveness of integrative couple therapy and integrative behavioral couple therapy on increasing the resilience of couples affected by infidelity.

Method: The present study is a quasi-experimental study with a pre-test-post-test design with a control group. The statistical population of the study includes couples who committed adultery and have referred to counseling centers in Andishe city in 2018. 24 couples were randomly assigned to three groups (two experimental groups and one control group) by available sampling. The Subjects answered Connor and Davidson resilience questionnaire. Univariate analysis of covariance was used to analyze the data.

Results: The results showed that integrative couple therapy $(\mathrm{F}=13 / 489, \boldsymbol{\eta} 2=0 / 325)$ and integrative behavioral couple therapy $(\mathrm{F}=31 / 988, \eta 2=0 / 533)$ re effective in increasing the resilience of couples affected by infidelity. Subjects scores in the post-test Connor and Davidson resilience scale had a significant increase compared to the pre-test scores $(\mathrm{p}<0.05)$.

Conclusion: Marital infidelity is a multi-causal phenomenon and since no single theory has a path to reality, considering the extent of harms and consequences of infidelity, based on the findings; it is suggested to use effective interventions of integrative approaches.
\end{abstract}

Keywords: Integrative couple therapy, Integrative behavioral couple therapy, Resilience, Infidelity

How to cite this article : Salari Feizabad H, Nouranipoor R, Zahrakar K. Comparison of the effectiveness of integrative couple therapy and integrative behavioral couple therapy on increasing the resilience of couples affected by infidelity. Shenakht Journal of Psychology and Psychiatry. 2021; 7 (6): 100-114 .URL: http://shenakht.muk.ac.ir/article-1-994-en.pdf

Copyright (C) 2018 the Author (s). Published by Kurdistan University of Medical Sciences. This is an open access article distributed under the terms of the Creative Commons Attribution-Non Commercial License 4.0 (CCBY-NC), where it is permissible to download, share, remix, transform, and buildup the work provided it is properly cited. The work cannot be used commercially without permission from the journal. 


\title{
مقايسه اثر بخشى زوج درمانى تركيبى و زوج درمانى رفتارى تركيبى بر افزايش تاب آورى زوجهاى آسيب ديده از خيانت
}

\author{
هاجر سالارى فيض آباد'، رحمت اله نورانى يور'، كيانوش زهراكارَّ \\ ا. انشجوى د كتراى مشاوره، گروه مشاوره، واحد علوم و تحقيقات، دانشخاه آزاد اسلامى، تهران ، ايران.

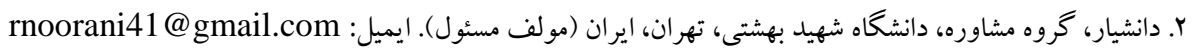

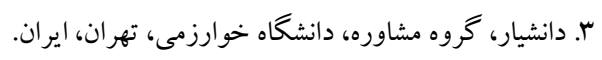

مقدمه: خيانت زناشويى زيان آورترين عمل به يك ارتباط است، اعتماد همسر آسيب ديده را از بين مىبرد، تابآورى را كاهش داده و ييامدهاى ناكوارى يديد مى آورد. هدف: بزوهش حاضر با هدف مقايسه اثر بخشى زوج درمانى تركيبى و زوج درمانى رفتارى تركيبى بر افزايش تاب آورى زوجهاى

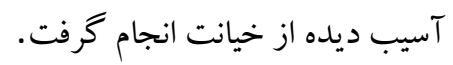
روش: يزوهش حاضر از نوع شبه آزمايشى با طرح ييش آزمون - يه آزمون با گروه كنترل است. جامعه آمارى شامل زوجهايى است

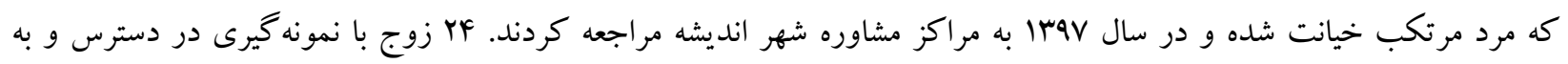

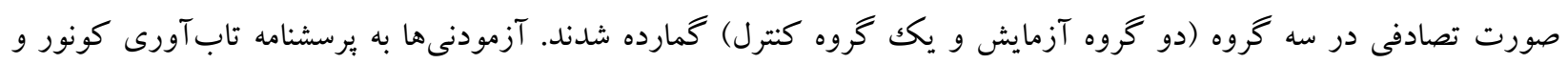
ديويدسون باسخ دادند. براى تجزيه و تحليل دادهها از روش تحليل كوواريانس تكك متغيرى استفاده شد.

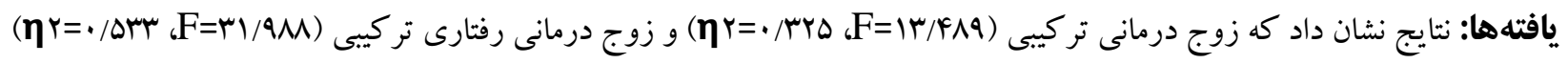

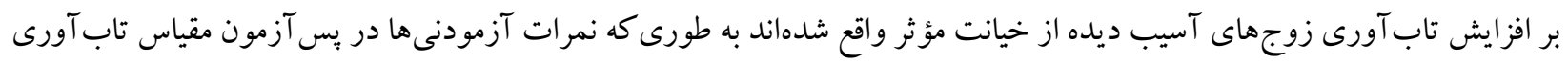

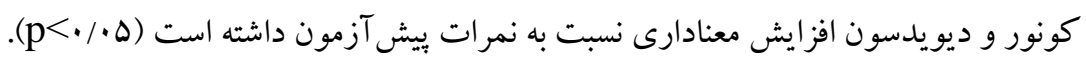
نتيجه كيرى: خيانت زناشويى يديدهاى جند عليتى است و از آنجا كه هيج نظريه واحدى مسيرى به سمت واقعيت ندارد. با توجه به

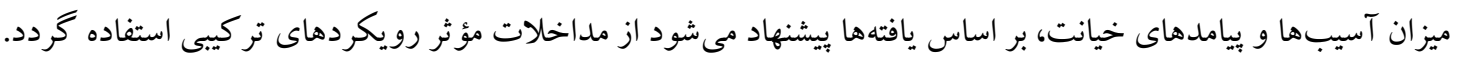
كليدوازهها: زوج درمانى تر كيبى، زوج درمانى رفتارى تركيبى، تاب آورى، خيانت 


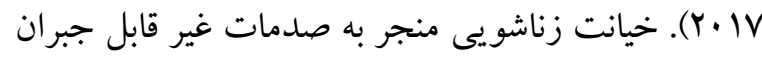
به زوجها شده و اعتماد و اطمينان همسرى كه آسيب ديده را از بين خواهد برد و ضربه شديد احساسى به طرفين مىشود. همسر آسيب ديده از خيانت زناشويى كه بىاعتمادى را تجربه كرده است، به صورت مكرر صحنهاى خيانت و تبادلات عاطفى همسر بيمانشكن خود را با معشوقهاش مرور كرده و واكنشهاى دفاعى را در مقابل همسر بيمانشكن خويش در بيش مى گيرد كه امكان هر گونه تبادل عاطفى و ايمن را از زوجها سلب و

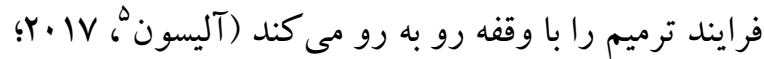

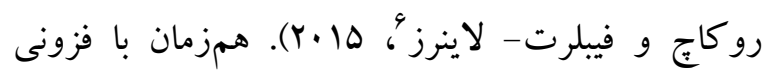
يافتن بىاعتمادى، همسر آسيب ديده مىيندارد كه شريك وى ديخر در دسترس و ياسخگوى احتياجهاى او نبوده و نمى توان روى سريرستى و حمايت وى در هنگام نياز حساب نمايد. در نتيجهى اين سرخوردگى، همسر آسيب ديده احساس طردشدگى و ناتوانى مى كند و اعتماد او به قابل اطمينان بودن و حمايتخر بودن همسر

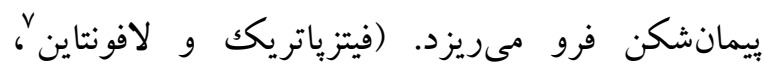
r. IV شرايطى همسر ان خيانت ديده دجار آشفتخى هاى شديدى

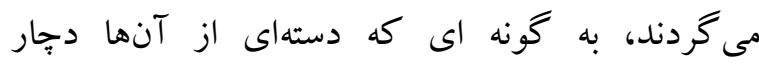

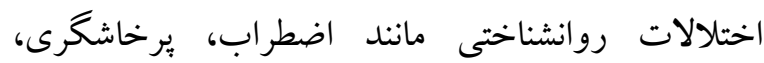
ناكامى، وسواس، سوءظن و بدبينى مىشوند و كروه ديخرى به رفتارهاى خود كشى دست مىزنند و دستهاى ديخر خانه را به قصد طلاق ترك مى نمايند؛ اما گروهى هستند كه سعى دارند با صبر و حوصله و آسيبشناسى دقيق و بدون از دست دادن كنترل رفتارى و هيجانى

5- Allison

6. Rokach \& Philibert-Lignieres

7 - Fitzpatrick \& Lafontaine

${ }^{8}$ - Halchuk, Makinen \& Johnson
مقدمه

خيانت زناشويى يكى از مهم ترين دلايل آسيب به زوجها و خانو ادهها و بهعنوان يكك يديده شايع براى خانو ادهها و زوج درمانگران است (كرد بجهه و عارفى، لوسM). افشاى يكك خيانت مىتواند تأثير مخربى بر روابط عاشقانه زوجها داشته باشد. يكك نظرسنجى از زوج درمانگران نشان مىدهد كه روابط فرا زناشويى نه تنها يكى از دشوارترين مسائل براى درمان هستند بلكه درمانگران نيز فاقد جهارجوب مفهومى روشن براى درك خيانت و در نتيجه مداخلات انجام شده هستند. (باكوم، ينتل، گوردون

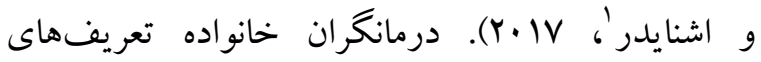
متعددى از خيانت زناشويى ارائه كردهاند كه از ميان ايشان، سوزان جانسون؛، خيانت زناشويى را به عنوان تخريب كرى بالقوه كه دلبستكى ايمن زوجها را تهديد و نيازهاى دلبستخى و ترس ايشان را بيش از بيش فعال مى لى سازد، تعريف مى كند و آن را زمينهساز بحرانهايى

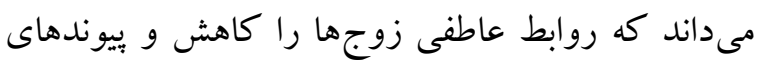
ارتباطى و ايمن ميان ايشان را سست مى گرداند (جانسون

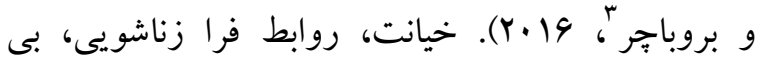
وفايى، قدم زدن، فريب دادن يا برخى از مترادفهاى ديخر نشان دهنده فعاليتهاى عاشقانه ينهانى با بارتنرى ديخر است، در حالى كه در رابطه منحصر به فردى مثل

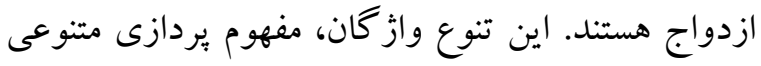
از فعاليتهاى ينهانى را منعكس مى كند كه مى تواند از درگيرى عاطفى با شخص ديخر (به صورت آنلاين يا حضورى) از گرفتن دست، نوازش، بوسه كرفته تا رابطه جنسى از طريق وازن و يا مقعد باشد (فينجام و مى'،

\footnotetext{
1. Baucom, Pentel, Gordon \&Snyder

2- Johnson

3. Johnson \& Brubacher

4- Fincham \& May
} 
سيستمى است. يكى از رويكردهاى تر كيبى كه محققان و

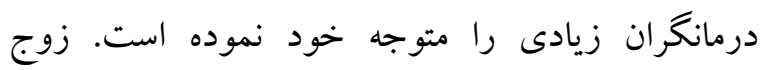
درمانى رفتارى تركيبى ' است. زوج درمانى رفتارى تركيبى، ريشه در زوج درمانى رفتارى سنتى د دارد .

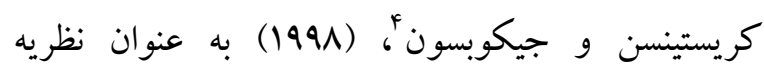
بردازان رويكرد رفتارى تركيب، معتقدند كه نمىتوان همه مسائلى را كه در اثر تفاوتهاى بين زوجها يديد آمده است با تغييرات رفتارى حل كرد. زوجها به مرور زمان تحمل خود را نسبت به تفاوتهايشان از دست مىدهند. در اصل هدف اصلى اين نوع درمان ايجاد يذيرش عاطفى زوجها نسبت به تفاوتهاى فعلى موجود بين آنها و تفاوتهايى است كه همواره مىتواند وجود داشته باشد. زوجدرمانى رفتارى تركيب، تركيبى از

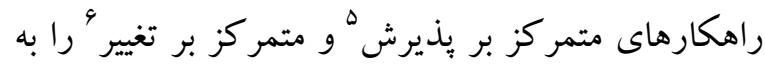

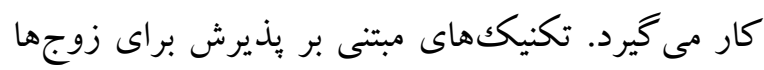
فرصتى را فراهم مىسازد تا مسائل خود را به ابزارهايى ليى ليكي براى افزايش صميميت تبديل كنند به منظور افزايش يذيرش هيجانى ميان زوجها از جهار شيوه استفاده

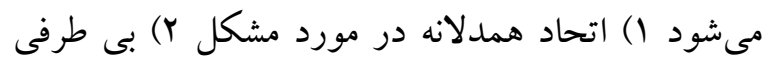
متحدانه در بررسى مشكل r) افزايش تحمل در مواجهه

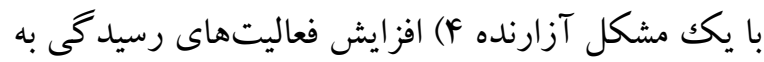
خود در برابر مشكلات لاينحل (كريميان، زارعى،

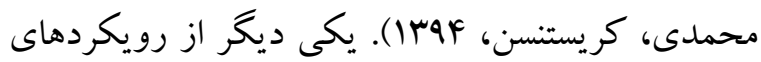
زوج درمانى تركيبى رويكردى است كه (اشنايدر و

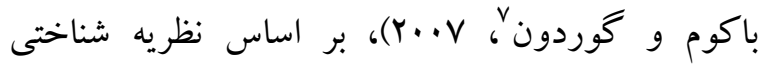
رفتارى، نظريه بخشودگى ' در روابط بين -فردى، نظريه

2- Integrative Behavioral Couple Therapy (IBCT)

${ }^{3}$ - Traditional Behavioral Couple Therapy (TBCT)

4- Christensen\&Jacobson

5 - Acceptance Focused Strategies

${ }^{6}$ - Change based

7- Snyder, Baucom \& Gordon

${ }^{8}$ - Cognitive - Behavioral Theory
خود، بر مشكلات جيره شوند. يرسش اساسى اين است كه جر ا برخى از همسر ان سعى مى كنند بر موانع و تجارب تلخ زندگى خود غلبه يابند و آن را از بين ببرند در حالى لى لى كه دسته ديخر خود را قربانى تجارب تلخ محيط مىدانند. محققان به عوامل مختلفى مانند حمايت اجتماعى، مؤلفهاى شخصيتى، تحصيلات و سوابق خود اشاره

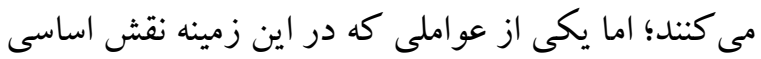
و جدى دارد، ميزان تابآورى' است. به ديخر سخن آنس يكى از عواملى كه تعيين كننده يُاسخهاى افراد در مقابل رويدادهاى استرس آفرين زندگى افراد مىباشد، ميزان

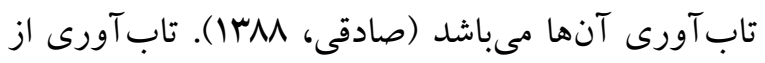
سازههاى مهم در روانشناسى است كه به تعالى فكرى و

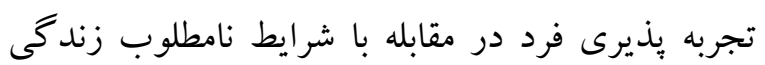

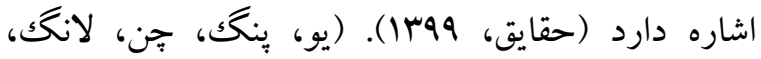

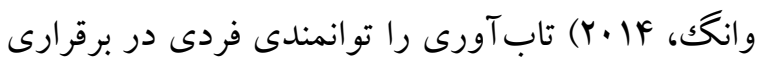
تعادل زيستى - روانى - معنوى در شرايط دشوار يا خطرناكك تعريف كردهاند. يُوهشهاى انجام شده در حوزه تابآورى و خيانت حاكى از آن است كه ميزان تابآورى همسران آسيب ديده از خيانت نسبت به همسرانى كه جنين تجربهاى نداشتند يايينتر است

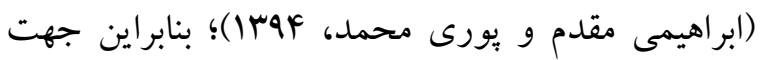
رشد تابآورى در همسران خيانت ديده كه با افزايش ساز كارى، بخش وسيعى از سلامت روانى فرد، خانواده فرد خيانت ديده و جامعه تأمين خو اهد شد نيازمند استفاده از طيف گستردهاى از يروتكلهاى درمانى هستيم كه بيش از · f سال تحقيق و تجربه در زمينه زوج درمانى اثر بخشى آنها را تأييد كرده است از جمله آنها رويكردهاى شناختى - رفتارى، بينش محور، هيجانى و

\footnotetext{
1- Resilience
} 
خواهد شد؛ و از سوى ديخر انجام جنين بثزوهشهايى به دليل ماهيت تر كيبى و داشتن ديدگاهى وسيع و همه جانبه به بديده جند عليتى خيانت، علاوه بر آن كه از اثربخشى بالايى برخوردارند، مقرون به صرفه و بسيار ضرورى نيز هستند؛ بنابراين در اين بزوهش از دو رويكرد تركيبى

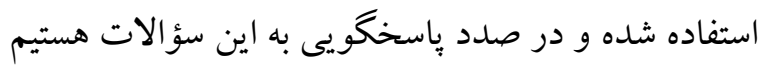
كه: ا- آيا زوج درمانى رفتارى تركيبى تأثيرى بر افزايش تاب آورى زوجهاى آسيب ديده از خيانت دارد؟ ب - آيا زوج درمانى تركيبى تأثيرى بر افزايش تاب آورى زوج

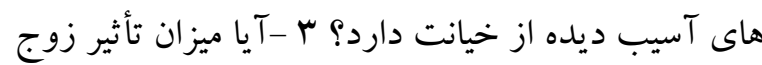
درمانى تركيبى و زوج درمانى رفتارى تركيبى بر افزايش تاب آورى زوجهاى آسيب ديده از خيانت متفاوت است؟

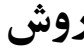

يثزوهش حاضر، از نوع شبه آزمايشى با طرح ييش آزمون

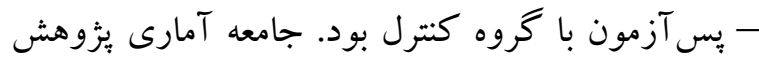
شامل زوجهايى بود كه مرد مرتكب خيانت شده، و در برد برد برد طى سال IM VV به مراكز مشاوره شهرستان شهريار (شهر انديشه) مراجعه كردند و جهت شركت در بزّوهش، رضايت آكًاهانه داشتند. در اين يزوهش از شيوه نمونه گيرى در دسترس استفاده شد. بدين صورت كه ابتدا به سازمان بهزيستى استان تهران و سبس به اداره بهزيستى شهرستان شهريار مراجعه گرديد. براساس معرفى نامه

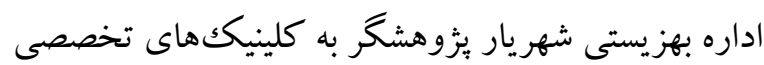
مشاوره و روانشناختى شهر انديشه، مراجعه نموده و مسئولين مربوطه را در جريان يثزوهش و روند اجراى يثوهش قرار داد و از مسئولين اين مراكز خواسته شد زوجين مواجه با مشكل خيانت همسر (مرد) را به

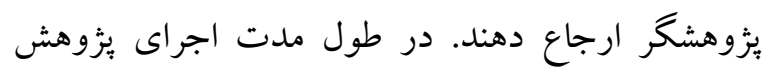

نظريه مبتنى بر بينش ׳و نظريه باسخ آسيبزا؟ّ درمان

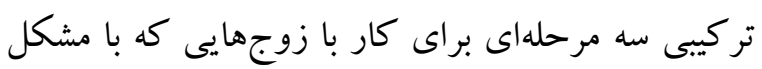
عهدشكنى زناشويى روبرو هستند، تدوين كردهاند. طبق اين نظريه خيانت به عنوان حادثهاى منفى و آسيبزا تعريف مىشود كه باورهاى اساسى همسران در مورد رابطهشان، همسرشان و خودشان را زير سؤال مىبرد. بر طبق مدل تركيبى درمان خيانت، داراى سه مرحله است:ا -شناسايى و فهم آثار آسيبزاى خيانت Y -فهم عواملى كه منجر به خيانت شده است ب -ادامه دادن به زندكى همراه با اين فهم جديد (آرين فر و اعتمادى، هوبا). اين رويكرد درمانى فرايند بهبودى از خيانت را مثل بهبودى از يكك تروما مفهومسازى مى كند (باكوم و همكاران، Y. Y. Y. براى تبيين مسئله خيانت رويكردهاى متعدد زوج درمانى به بررسى آن از ديدكاههاى مختلف يرداختهاند ولى بر اساس مطالعات موجود تفاوتهاى معتبرى در زمينه اثر بخشى اين درمان ها به دست نيامده است شايد يكى از دلايل اين نتايج اين است كه همه درمانها مبتنى بر اصول مشتركى هستند. هنوز هم آزمايشهاى تجربى بحث داغ درمانگران است و تعدادى از تحقيقات ضعف رويكردهاى تك مكتبى را نشان

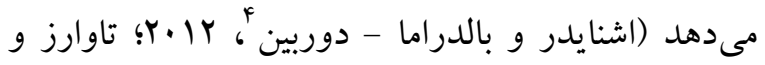

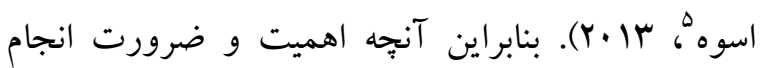
يثزوهشهاى تر كيبى را نمايان مىسازد از يكك سو جبران ضعف حاصل از رويكردهاى تكك مكتبى در تبيين مسائل روانشناختى انسان و مخصوصاً يديده خيانت، با توجه به ميزان آسيبها و بيامدهايى است كه در صورت غفلت از تمامى ابعاد آن، گريبان گير فرد، خانواده و جامعه بشرى

\footnotetext{
1. Forgiveness Theory

2. Insight-oriented theory

3 - Traumatic response theory

4- Snyder, Balderrama- Durbin

5 - Tavares, Aassve
} 
به درج نام نيست. گروههاى آزمايش مداخلات زوج درمانى · · جلسهاى مربوط به زوج درمانى تركيبى و زوج درمانى رفتارى تركيبى را طى دو ماه و نيم به صورت هفتخى (هر جلسه ·9 دقيقه) دريافت نمودند و كروه كنترل هيج درمانى دريافت نكرد. اجراى ييش آزمون و پِ آزمون طبق بروتكل هاى زوج درمانى به انجام رسيد. براى انجام اين ئزوهش ابتدا متون علمى مربوط به اين دو رويكرد جهت تهيه يروتكل هاى درمانى مطالعه شد. در تهيه ساختار كلى رويكرد تر كيبى از (كريمى، (qها) استفاده شده است اما جهت مشروح جلسات زوج درمانى تركيبى از منابع (كوردون، باكوم و اشنايدر و ديكسون به

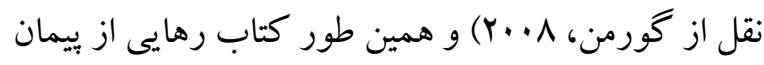

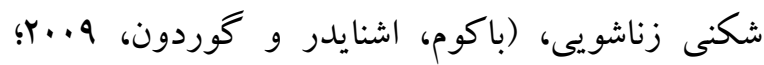
ترجمه موزيرى و نادرى، هوب(1) استفاده شده است. همين طور براى ساختار كلى رويكرد رفتارى تركيبى از (كريميان، هوبا) استفاده شده است اما جهت تهيه مشروح جلسات درمانى رفتارى تركيبى از منابع

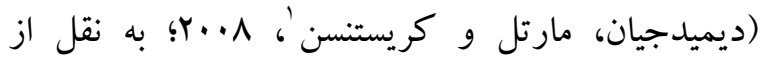

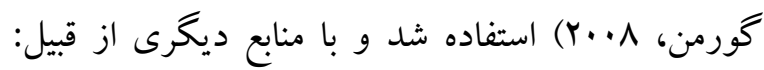

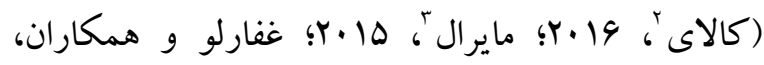
هوس|) تطبيق داده شد. در اين بثوهش براى تجزيه و تحليل دادهها از دو سطح آمار توصيفى و استنباطى استفاده شد. در سطح توصيفى از ميانگين و انحراف استاندارد و در سطح استباطى از آزمون لوين براى بررسى برابرى واريانسها و همجنين از تحليل كوواريانس تكك متغيرى براى بررسى فرضيه هاى بيزوهش برى

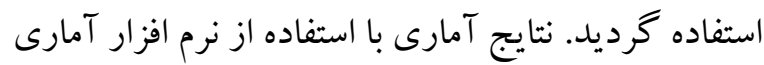
SPSS-rه، مورد تجزيه و تحليل قرار گرفت.

1. Dimidjian, Martell \& Christensen

2- Kalai

${ }^{3}$ - Mairal
كليهى زوجين مواجه با خيانت همسر (مرد)، YV زوج، در

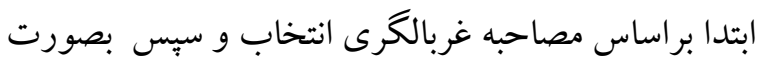
جايكزينى تصادفى در ب گروه زوج درمانى تر كيبى (هزوج)، زوج درمانى رفتارى تركيبى (q زوج) و گروه كنترل (q زوج) جايكزين شدند. از YV زوج انتخاب شده، (ا زوج از گروه زوج درمانى تركيبى و ا زوج از گروه زوج درمانى رفتارى تركيبى) در جلسات ابتدايى از ادامه كار منصرف شدند. از گروه كنترل نيز ا زوج يس آزمون را انجام ندادند. ملاككهاى ورود به يثوهش شامل: 1زوجينى كه مسأله خيانت زناشويى در آنها تمام شده باشد Y -داراى تحصيلات حداقل سيكل باشند ب - مايل به همكارى جهت دريافت مداخلات مشاورهاى باشند -زوجهايى كه دامنه سنى بين له تا ها سال دارند ه زوجهايى كه هر دو بتوانند به صورت حداقل ·ـ جلسه بيايى در جلسات مشاوره شركت كنند 9 -زوجهايى كه حداقل يك سال سابقه زندگى مشترك دارند V- تاب آورى پِائينى دارند و همجنين ملاككهاى خروج نيز عبارتند از: ا- وجود اختلال شخصيتى حاد در يكى از زوجها ب-دريافت مداخلات دارويى از جانب يكى از زوجها سـز زوجهايى كه در زمان مراجعه، همسر به خيانت خود يايان نداده باشد F-ززوجهايى كه همسر خيانتهاى متعدد دارد ه -زووجهايى كه يكى از همسران اعتياد دارد 9-عدم تمايل به ادامه ئزوهش. جهت رعايت اخلاق در يثزوهش رضايت زوجها براى شركت در برنامه مداخله، كسب و از كليه مراحل مداخله آكاه شدند. همجنين به افراد كروه كنترل اطمينان داده شد كه آنان نيز يس از اتمام فرايند يزوهشى مداخلات زوج درمانى را

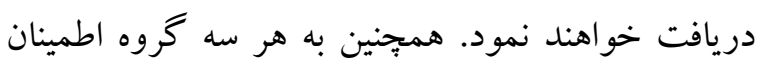
داده شد كه اطلاعات آنها محرمانه باقى مىماند و نيازى 
جدول ا ساختار جلسات زوجدرمانى رفتارى تر كيبى (كريميان و همكاران، هوسا)

مداخلات

عنوان جلسه

\section{جلسه}

\begin{tabular}{|c|c|}
\hline 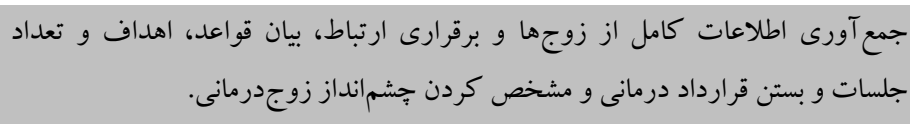 & ر قالب جلسه مشتر كك بر ارتباط و ارزيابى \\
\hline 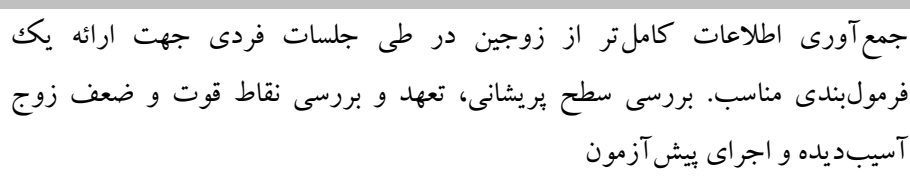 & جلسه دوم و سوم: برغزارى جلسات \\
\hline موضوائه ديد گاه درمانگر از فرمولبندى و همخوانى آن با ديد كاه زوجها، تحليل عميق كليه & مشكلات جهارم و ونجم: فرمولبندى ارئه بازخورد به زوجها \\
\hline
\end{tabular}

جلسه ششم: بررسى الخوهاى تعاملى اين جلسه نيز در راستاى جلسه قبل و در جهت تحليل كليه موضوعاتى است كه منجر به ونه

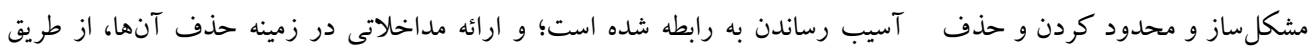

$$
\text { تمر كز بر اينجا و اكنون. }
$$

آن

مرحله

ارزيابى

\section{مرحله بازخورد و} فرمولبندى

جلسه هفتم: هدف الحاق همدلانه، مداخلات مبتنى بر هيجان: شناسايى هيجانهاى اوليه ف افشاى هيجانها، تمركز روى

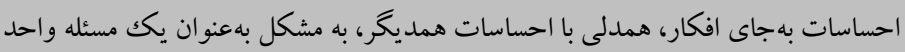

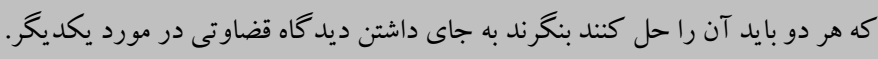

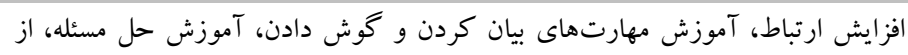

$$
\text { طريق تعريف مسئله، شيوه بارش فكرى، آزمايش كردن در محيط خارج از جلسه. }
$$

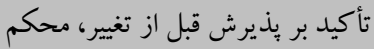
و جداسازى واحد

از طريق برجسته ساختن ويثز گهاى مثبت رفتارهاى منفى، مرور ذهنى رفتار منفى،

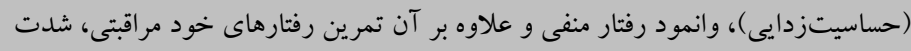

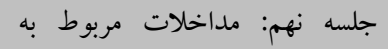

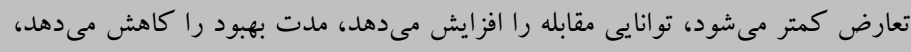

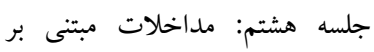
رفتار: (با هدف تغيير رفتار)

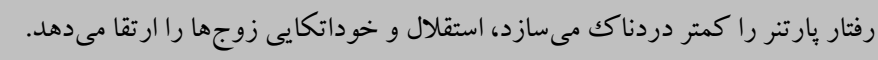

\begin{tabular}{|c|c|c|}
\hline مداخلات & عنوان جلسه & جلسه \\
\hline 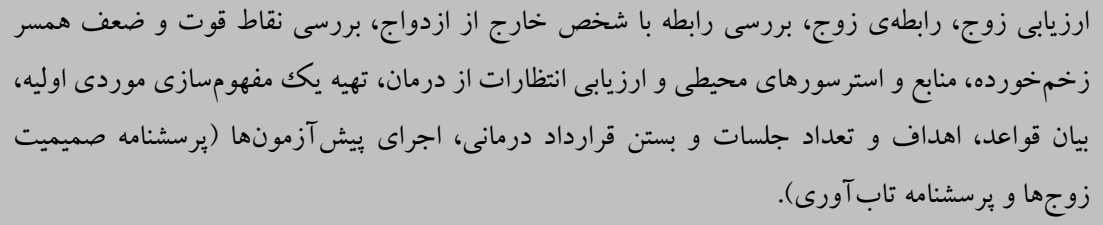 & ارزيابى زوجهارى ارتباط و & اول \\
\hline 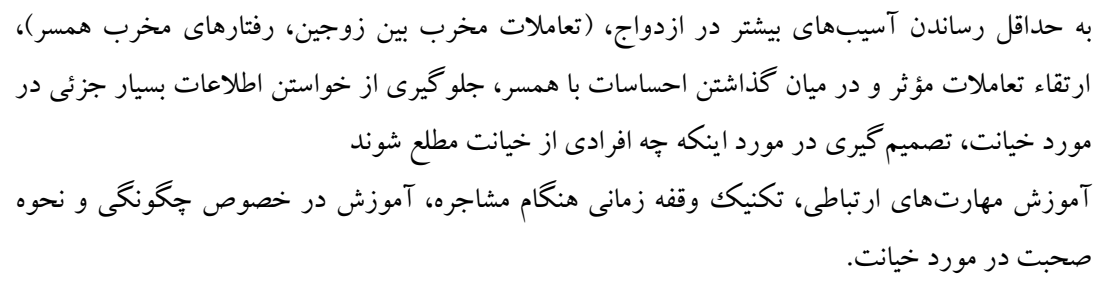 & كنترل آسيبهاى & دوم \\
\hline بهبود آسيبهاى ايجادشده در حيطه روابط بين دو همسر (وظايف روزمره هر يكك از همسران، فعاليتهايى & 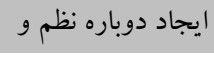 & 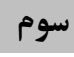 \\
\hline
\end{tabular}

$$
\begin{aligned}
& \text { جلسه دهم: جمعبندى، كمكك به بحث در مورد دستاوردهاى درمان و تصميم راجع به آينده } \\
& \text { زوج براى كنار آمدن با عوامل } \\
& \text { فشارزا، اجر ایى يس آزمون }
\end{aligned}
$$

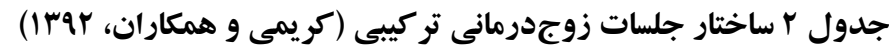


تعادل در زندكى كه نياز به همراهى هر دو همسر دارد، فعاليتهاى صميمانه)، بهبود آسيب بر حوزه عملكرد فردى (في

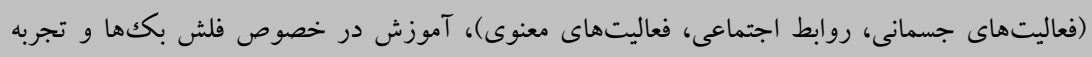

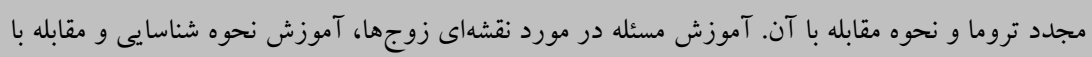
فلش بككها.

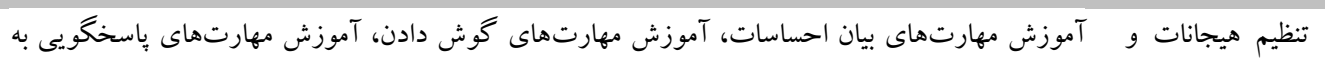
در ميان گذاشتن احساسات، تعيين زمانهايى براى صحبت كردن در مورد خيانت خارج از جلسه، نوشتن نامه توسط همسر زخمخورده به همسر در مورد احساسات خود در مورد خيانت. آن با همسر

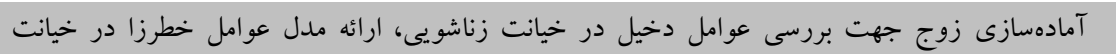

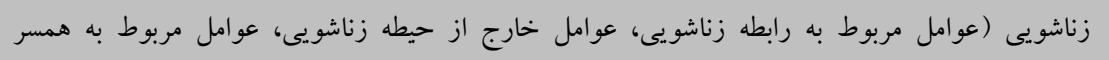

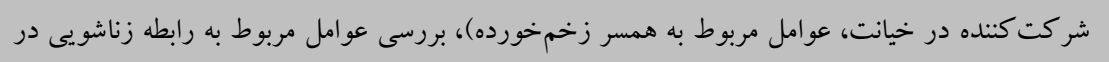

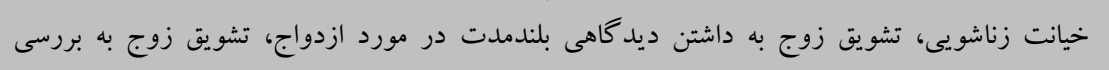

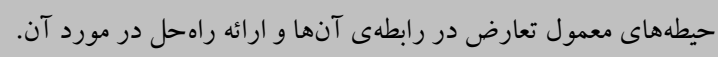

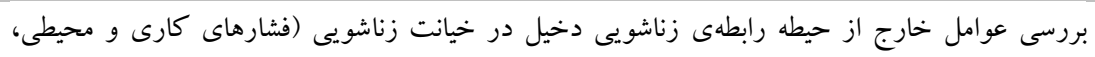

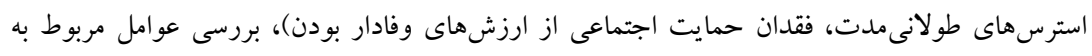

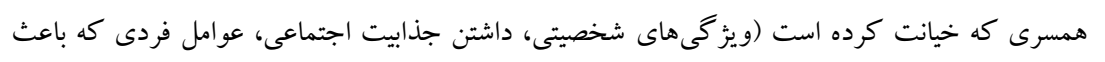
تداوم خيانت شده است). شناسايى و نوشتن منابع خارج از حيطه زناشويى كه تأثير منفى بر ازدواج داشته

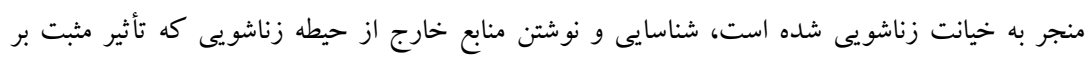

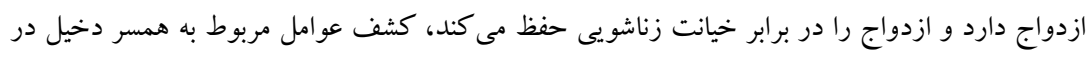
خيانت، كشف عوامل مربوط به همسر كه باعث تداوم خيانت شده است.

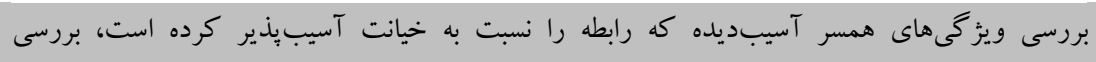

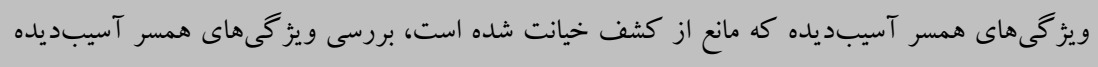

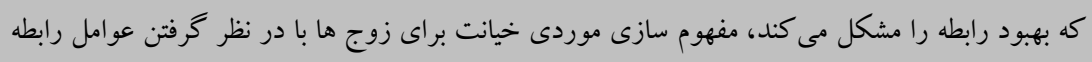

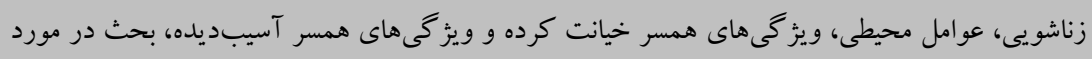

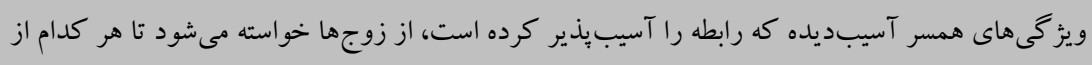

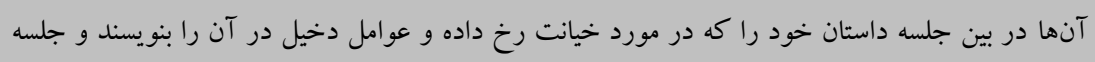
بعد با خود به جلسه بياورند.

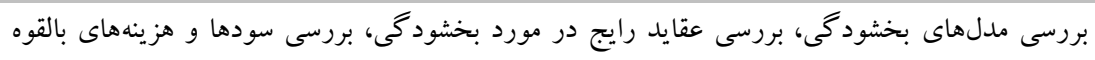

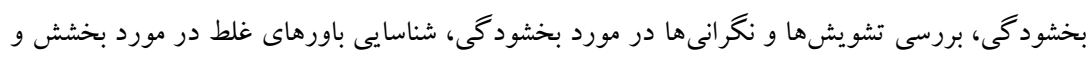

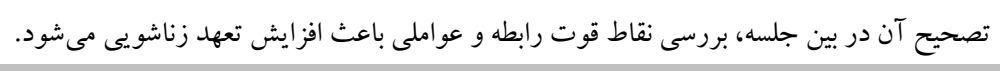

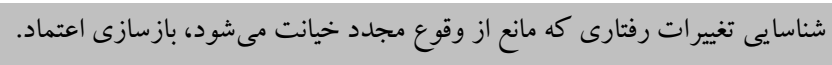

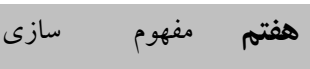
موردى در مورد عوامل دخيل درد درد دورد خيانت زناشويى

جهارم كشف عواملى كه با همبر منجر به خيانت به

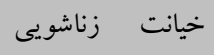
شده است ششم كشف عواملى كه منجر به به غيانت شده است

\section{هنجم}

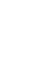

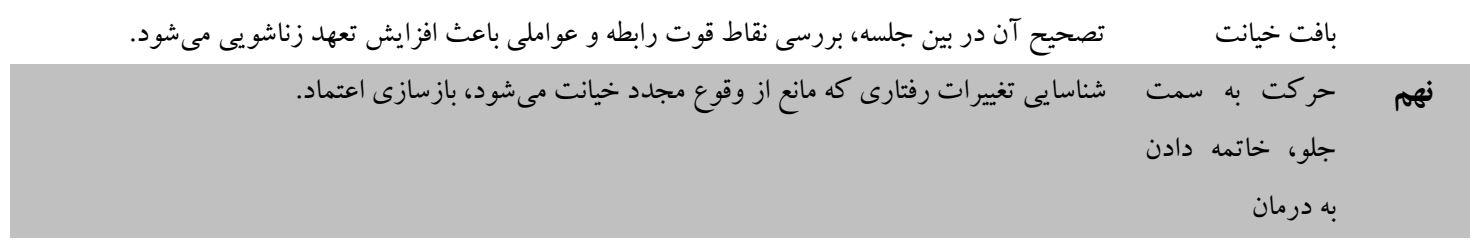

دهم خاتمه دادن به بررسى اظهارنظر زوجها در ميزان دستيابى به اهداف تعيينشده، مرورى بر مداخلات صورت گرفته و

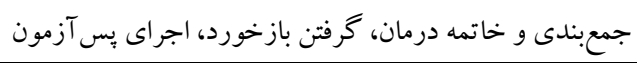
هشتم بررسى مسئله بخشودگ بافت خيانت نهم حركت به سمت جلو، خاته درمان 
را بدست آوردند، نشان دهنده خصوصيات روان سنجى مطلوب اين مقياس بوده و ابزار مناسبى براى اندازه گيرى است. همجنين در بزظوهش حاج محمد رضا (هوسا)، ضريب اعتبار مقياس تابآورى با آلفاى كرونباخ

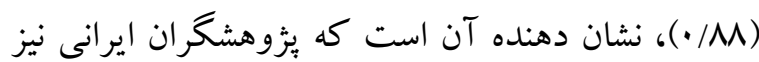
ضريب يايايى مناسبى براى اين مقياس گزارش كردهاند.

يافتهها در اين بُزوهش جهت تجزيه و تحليل دادههاى به دست آمده از ابزارها، روشهاى آمارى توصيفى (ميانگين و وهري

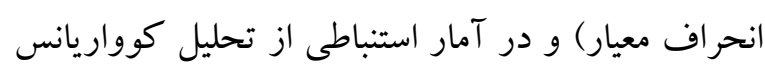
تكك متغيرى استفاده شد. يافتها در دو شاخص توصيفى و استباطى ارائه گرديده است. با توجه به مشخصات

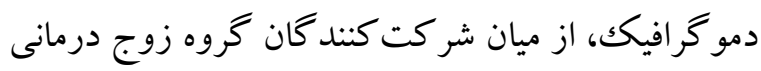
تركيبى 9 نفر داراى تحصيلات سيكل، F نفر دييلم، Y نفر فوق دييلم و F نفر داراى تحصيلات ليسانس بودند و در كروه زوج درمانى رفتارى تركيبى \& نفر داراى تحصيلات سيكل، 9 نفر دييلم و 9 نفر داراى تحصيلات ليسانس بودند و در گروه كنترل r نفر داراى تحصيلات سيكل، F نفر دييلم، 4 نفر فوق دييلم و F نفر داراى تحصيلات ليسانس بودند. در مورد وضعيت اشتغال در كروه زوج درمانى تركيبى 9 نفر شاغل و V نفر خانهدار بودند، در گروه زوج درمانى رفتارى تركيبى 4 نفر

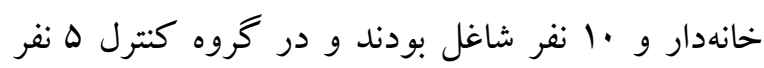
خانهدار و 1ل نفر شاغل بودند. در جدول شماره م ميانگين و انحراف استاندارد متغير مورد مطالعه در زوج درمانى تركيبى و زوج درمانى رفتارى تركيبى گزارش شده است.
اين برسشنامه را كونور و ديويدسون’ (r..r) با مرور منابع يزوهشى 19V9-1991، حوزه تابآورى تهيه كردند. بررسى ويزگ مهى هاى روانسنجى اين مقياس در

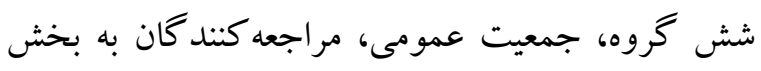
مراقبت هاى اوليه، بيماران سريايى و روانيزشكى، بيماران با مشكل اختلال اضطراب فراگير و دو گروه از بيماران استرس بِ از سانحه، انجام شده است. تهيه كنند گان اين مقياس بر اين باورند كه اين يرسشنامه به خوبى قادر به

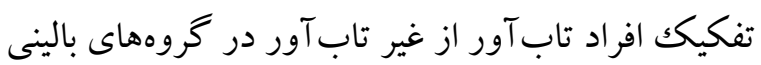
و غير بالينى بوده و مى تواند در موقعيت هاى بثزوهشى و

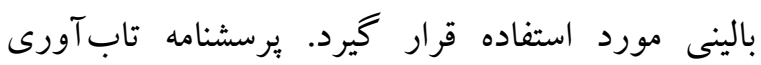
كونور و ديويدسون ها عبارت دارد كه در يكك مقياس ليكرتى بين صفر (كاملاً نادرست) تا جِهار (كاملاً درست) نمره گذارى مىشود. نمره گذارى گزينها دها در اين مقياس به شرح زير است: كاملاً نادرسـت = " بهندرت =ال، كاهى r= نمرات آزمون بـين · تا . . إقرار دارد نمرات بالاتر بيانگر

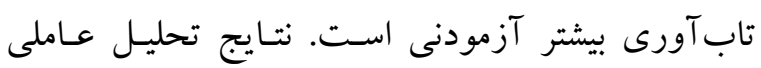
حـاكى از آن هستند كه اين آزمون داراى ه عامل: تصور شايستخى فردى، اعتماد به غرايز فردى، تحمل عاطفـه إنه إنه منفى، يذيرش مثبت تغيير و روابط ايمن، كنترل و تأثيرات معنوى است. كونور و ديويدسون ضريب آلفاى كرونبـاخ مقياس تاب آورى را 119/ • كزارش كردهاند. همجنين ضريب پيايايى حاصل از روش باز آزمايى در

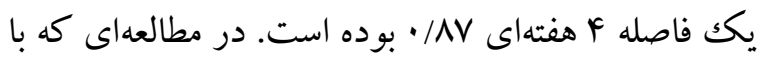
هدف بررسى خصوصيات روان سنجى مقياس تاب آورى كونور - ديويد سون توسط (آلاركون، سرزو، هويلا،

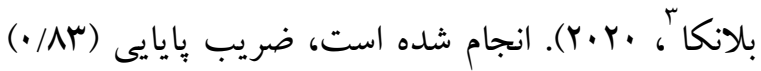

1- Connor and Davidson resilience questionnaire

2- Connor \& Davidson

3. Alarcón, Cerezo, Hevilla, \& Blanca 


\begin{tabular}{|c|c|c|c|c|c|}
\hline \multicolumn{2}{|c|}{ يس آزمون } & \multicolumn{2}{|c|}{ ي يش آزمون } & \multirow{3}{*}{ كروه } & \multirow{3}{*}{ متغير } \\
\hline 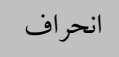 & ميانگين & 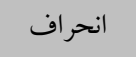 & ميانگين & & \\
\hline استاندارد & & استاندارد & & & \\
\hline IF/GYAG. & $\mathrm{FF} / .9 \mathrm{TQ}$ & W/FFIMA & MT/GYO. & زوجدرمانى تر كيبى & \multirow[t]{2}{*}{ تاب آورى } \\
\hline $1 \cdot / 1 \mathrm{~V} \cdot 99$ & $q V / r \ldots$ & F/DQMFV & $q \pi / \Delta \ldots$ & زوجدرمانى رفتارى تر كيبى & \\
\hline
\end{tabular}

آزمون برقرار باشد كه عبارتاند از: برقرارى رابطه خطى، فرض برابرى واريانسها، همخنى شيب رگرسيون، نرمال

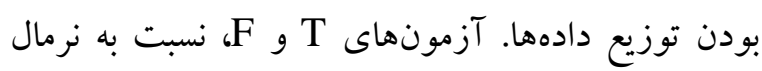
بودن توزيع دادهها و برقرارى رابطه خطى مقاوم هستند

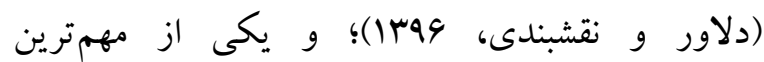
مفروضهها، مفروضه برابرى واريانسهاست كه نتايج آن در جدول شماره F نشان داده شده است.
با توجه به نتايج جدول م ميانگين و انحراف معيار در پس آزمون متغير تابآورى در زوجهاى آسيب ديده از خيانت در گروههاى آزمايشى بعد از اجراى زوج درمانى لمدي رفتارى و زوج درمانى رفتارى تركيبى نسبت به ييش آزمون افزايش داشته است. براى بررسى اثربخشى زوج درمانى تركيبى و زوج درمانى رفتارى تركيبى از روش تحليل كوواريانس تكك متغيرى استفاده شده است. به منظور آزمون تحليل كوواريانس بايد مفروضههاى اين

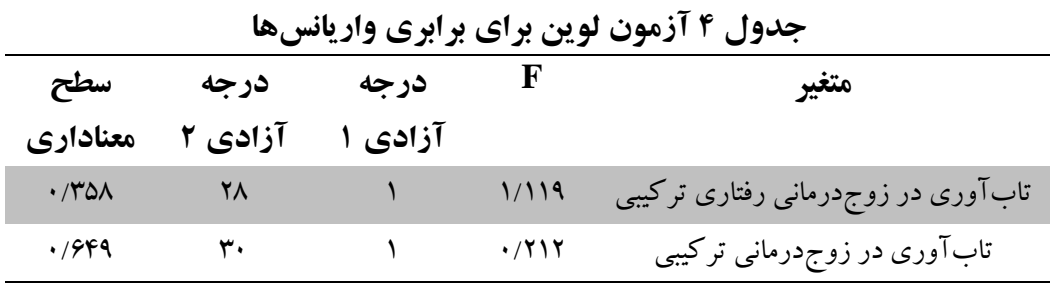

بنابراين، مفروضه برابرى واريانسها تأييد مىشود. در نتايج جدول \& بيانگر آن است كه مقدار F تعامل معنىدار راستاى آزمون فرضيه، نتايج تحليل كوواريانس تكك نيست. مقدار f در زوج درمانى رفتارى تركيبى براساس متغيرى بر روى ميانگين نمرات بس آزمون تابآورى

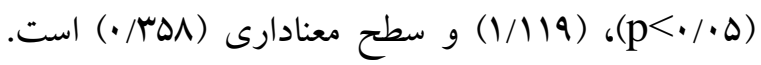
كروه آزمايشى (زوج درمانى رفتارى تركيبى) در جدول همين طور مقدار f در زوج درمانى تر كيبى نيز براساس هارائه شده است.

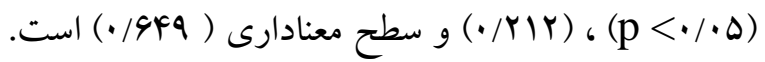

\begin{tabular}{|c|c|c|c|c|c|c|}
\hline اندازه & معنادارى سطح & $\mathbf{F}$ & مجذوراتين & آزادى درجه & مجذمورات & منبع براكند \\
\hline$\cdot / \Delta T r$ & $\cdot / \cdots$ & rI/9MM & rrDN/DIQ & 1 & rrDA/DIG & زوجدرمانى رفتارى تر كيبى \\
\hline & & & $V+/ N r$. & r^ & $r \cdot q F / F F D$ & خطا \\
\hline
\end{tabular}


معنادار شده است. ميزان تأثير زوج درمانى رفتارى

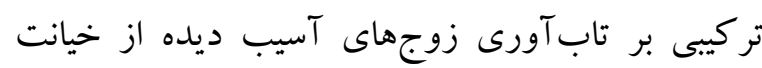
(بسه/•) است. اين بدان معناست كه به درصد افزايش تابآورى در زوجها توسط ارائه متغير مستقل (زوج آنان درمانى رفتارى تركيبى) تبيين مىشود. براى آزمون

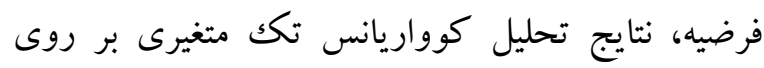

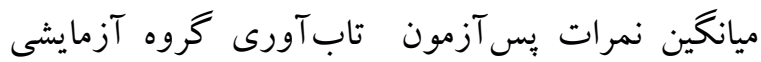
دوم (زوج درمانى تر كيبى) در جدول 9 ارائه شده است.
نتايج تحليل كوواريانس مندرج در جدول (ه) نشان مىدهد كه ارائه متغير مستقل (زوج درمانى رفتارى

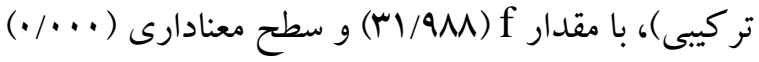
براساس (ه/•) ميانكين نمرات متغير وابسته (تاب آورى) در مرحله بس آزمون در سطح خطاى هـ/. گردد ؛ لذا اين نتيجه حاصل مىشود كه با كنترل متغير مداخله (بيش آزمون)، ميانكين نمرات متغير تابآورى دجار تغيير

\begin{tabular}{|c|c|c|c|c|c|c|}
\hline اندازه & معنادارى سطح & $\mathbf{F}$ & مجذوراتكين & آزادى درجه & مجذوروات & منبع براكندكى \\
\hline \multirow[t]{2}{*}{$\cdot \pi T \Delta$} &.$/ \cdot 1$ & $\mid r / F \wedge 9$ & $\Delta r N / 9 \mid 9$ & 1 & 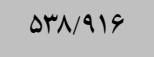 & زوجدرمانى تر كيبى \\
\hline & & & $r q / q \Delta F$ & rA & $\| 1 / N / v \ldots$ & خطا \\
\hline
\end{tabular}

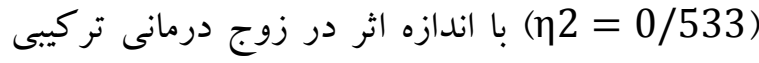
از طريق تبديل آنها به نمره Z = 0/325) مقايسه آنها با يكديخر با توجه به سطح معنادارى (1/94)

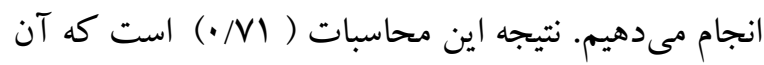
را با سطح معنادارى (1/99) مقايسه كرده و در نتيجه مى توانيم بكوييم كه تفاوتى از نظر اثربخشى بين دو زوج درمانى در افزايش تابآورى وجود نداشته ( هـ/•> بنابراين اثر دو رويكرد در ميزان افزايش تابآورى آورى مساوى است.

بحث يثزوهش حاضر با هدف مقايسه اثر بخشى زوج درمانى تركيبى و زوج درمانى رفتارى تركيبى بر افزايش تاب آورى زوجهاى آسيب ديده از خيانت انجام كرفت. نتايج يزوهش نشان داد كه زوج درمانى تركيبى و زوج درمانى رفتارى تركيبى هر دو منجر به افزايش ميزان
نتايج تحليل كوواريانس مندرج در جدول 9 نشان مىدهد ارائه متغير مستقل (زوج درمانى تركيب)، با مقدار

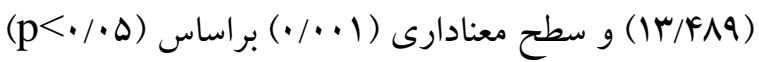
توانسته منجر به ايجاد تفاوت معنادار ميانگين نمرات متغير وابسته (تاب آورى) در مرحله يس آزمون در سطح خطاى ه•/ • رددد ؛ لذا اين نتيجه حاصل مىشود كه با كنترل متغير مداخله گر (ييش آزمون)، ميانگين نمرات متغير

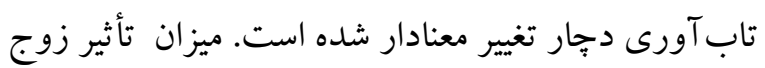
درمانى تركيى بر تاب آورى زوجهاى آسيب ديده از خيانت(هץ//) است. اين بدان معناست كه بr درصد افزايش تابآورى در زوجها توسط ارائه متغير مستقل (زوج درمانى تركيبى) تبيين مى شود. به منظور بررسى فرضيه نهايى يعنى ميز ان تفاوت در اثربخشى زوج درمانى تركيبى و زوج درمانى رفتارى تركيبى بر افزايش تابآورى زوجهاى آسيب ديده، اندازه اثر متغير

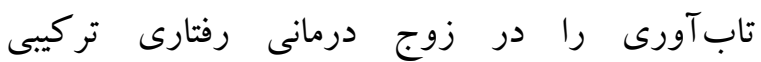


نشود سرزنش طرف مقابل حذف مىشود و يا كاهش مىيابد. سرزنش كردن جزء عوامل دور كننده افراد از يكديخر است و هر هُقدر سرزنش در رابطه كمتر باشد به همان نسبت تعامل و كفتخً بيشتر شده و در نتيجه منجر به بهبود صميميت و افزايش تاب آورى مىشود (خجسته

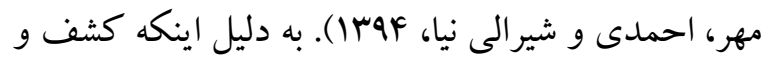
بر ملا شدن خيانت معمولا منجر به آشفتكى هاى هيجانى و تعاملات منفى بين زوجين مىشود، راهبردهاى با ساختار و مستقيم كه در زوج درمانى شناختى - رفتارى وجود دارد به زوجين كمكك مى كند تا آشفتخىهاى هيجانى كمترى را تجربه كنند و از شدت تعاملات منفى شان كاسته شود. علاوه بر اين، براى فهم عواملى كه رابطه را نسبت به خيانت آسيب يذير مى كند زوجين به اين نياز

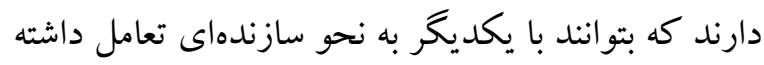
باشند و جالشهاى رابطه زناشويى را مديريت كنند. در خصوص مقايسه ميزان اثر بخشى زوج درمانى تركيبى و زوج درمانى رفتارى تركيبى نتايج يزوهش نشان داد كه

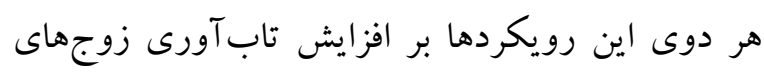
آسيب ديده از خيانت با اندكى تفاوت و به يكك ميزان موثر واقع شدهاند. ئزوهش مشابهى كه به طور دقيق و به همين روش به بررسى مقايسه اثربخشى اين دو رويكرد

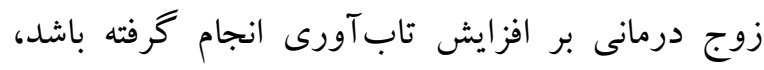
يافت نشد. نتايج ئوهش حاضر در خصوص اثربخشى برى زوج درمانىهاى يكيارجهنگ در رابطه با زوجهاى آسيب

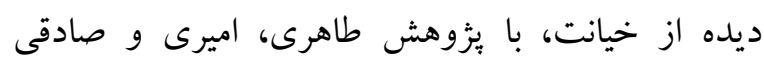
اردوبارى، هوسا و كريمى و همكاران، اهو| همسو مىباشد. و در اين خصوص يثوهش ناهمسويى يافت نشد. كريمى و همكاران، در يثوهش خود مبنى بر،

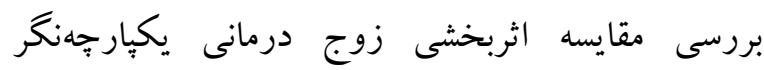

تاب آورى زوجهاى آسيب ديده از خيانت شدهاند و در اين رابطه هيج كدام از اين دو درمان برترى معنادارى ندارند. يثزوهش مشابهى كه به طور دقيق و به همين روش به بررسى مقايسه اثربخشى اين دو رويكرد زوج درمانى بر افزايش تاب آورى زوجها، انجام گرفته باشد، يافت نشد. بند نتايج يثزوهش حاضر در خصوص اثربخشى زوج

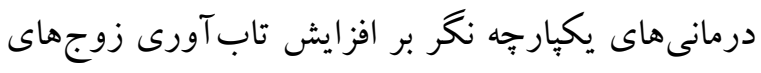
آسيب ديده از خيانت همسو با نتايج بثوهش، اسفنديارى بيات، اسديور، محسن زاده، كسايى، 99با؛ عمادى الهيارى، آتش بور، عqrا؛ آقا گدى، گل برور، آقايى، خياطان، VqMا؛ مارين، كريستنسن، اتكينز،

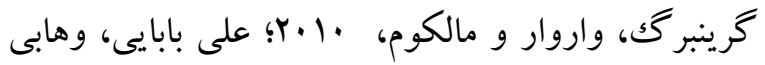
همابادى، خالقى :يور، \هبا؛ همسو بوده و در اين خصوص يثزوهش ناهمسويى يافت نشد. در تبيين و تشريح زوج درمانى رفتارى - تر كيبى مىتوان كفت كه درمان رفتارى تر كيبى علاوه بر تخليه و بذيرش هيجانى به تغيير رفتار و تقويت الكوهاى رفتارى و دستاوردهاى مثبت مى بردازد. همجينين درمان رفتارى تركيبى تلاش دارد ميزان تحمل و تابآورى فرد دريافت كننده رفتار منفى را افزايش دهد تا در صورت تغيير نكردن فرد مشكل ساز، شريك ديخر قادر به تحمل اين رفتارها و شرايط ناخوشايند باشد (كريميان و همكاران، هوس1). همجنين در خصوص اثربخشى زوج درمانى تركيبى، مىتوان جنين استدلال نمود كه زوج درمانى تركيبى به زوجها

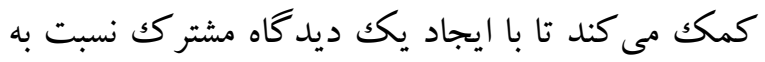
خيانت و تعريف آن به صورت مشكل دو جانبه، هر دو نفر به نوعى به نقش خود در ايجاد و تداوم خيانت يى نه ببرند. در واقع زوج به اين نتيجه مىرسد كه تنها عامل خيانت، همسرش نيست. وقتى همسر عامل مشكل قلمداد 
اسـت. آزمسودنىهـاى يُزوهش به رغم اينكه مورد

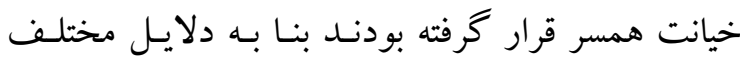
خواهان طلاق و جدايى نبوده و عمده ترين انخيزهُ آنها حفظ كـانون گحرم خـانوادگى و آينده فرزندان بود به به همين دليل آنها بيشتر متمايل به حفظ و ساختن زندكى

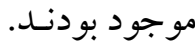

\section{نتيجه كيرى}

نتايج يزوهش حاضر نشان داد كـه مستـوان زوج درمانى

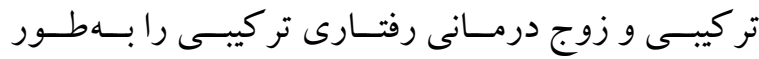
موفقيت آميزى براى افزايش تـاب آورى زوجين آسـيب ديده از خيانت به كار گرفت و هيج كدام از اين دو درمان در مقايسه با ديخرى برترى معنادارى در اثربخشى درمانى نداشـتند؛ لـذا هـردو درمـان مـىتوانـــ در افز ايش ميـزان تاب آورى زوجين مورد استفاده قرار كيرنــ و بهتـر اسـت برترى اثربخشى هر كدام از ايسن درمـانهـا كـه در برخى تحقيقـات ذكــ شـده را بـه نتـايج مطالعـات فراتحليـل وسيع ترى كه در آينده انجام خواهد شــد موكـول نمـاييم. نهايتا مى توان استـدلال كرد كـه زوج درمـانى تر كيبى و زوج درمانى رفتارى تركيبى بـهـ شـكل برابـرى بـه عنـوان

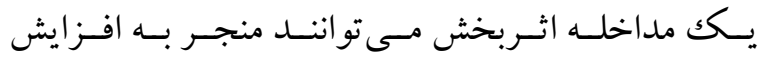
تاب آورى و بهبود كيفيت زندگى زوجين گردند. يثزوهش حاضر با محدوديت هايى از قبيل كم بودن حجم نمونه، كوتاه بودن طول مدت درمان، نداشتن مرحله ييگيرى و ارتباط مستمر با زوجها و عدم اطمينان از يايدارى نتايج، مواجه است. از ديخر محدوديتهاى اين يثزوهش مى توان به عدم تعميم نتايج به مردان آسيب ديده

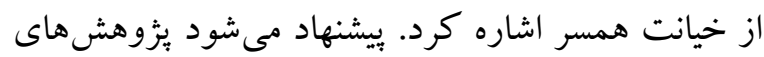
بعدى از نمونهاى با حجم بيشتر و جلسات رواندرمانى
(تركيب) و زوج درمانى هيجان مدار بر كاهش آسيب هاى ناشى از خيانت زناشويى به اين نتيجه رسيدند كه هر دو زوج درمانى در كاهش افسردگى و علائم استرس بس از سانحه هم در كوتاه مدت و هم در بلند مدت اثر تقريبا يكسانى دارند اما در افزايش صميميت و بخشودگى هم در كوتاه مدت و هم در بلند مدت زوج درمانى يكيارجه نَخر موثرتر از زوج درمانى هيجان مدار است و جنين استدلال مى كنند كه زوج درمانى يكِيارجهنگ مدل كاملا روشن و واضحى در مورد خيانت دارد و از ابتدا براى كار با زوجين درگير با خيانت زناشويى ايجاد شده است. همجنين در زوج درمانى

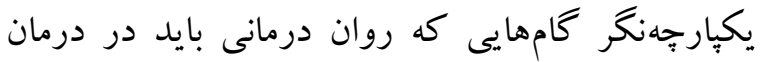
خيانت طى كند كاملا مشخص است كه امكان اجراى

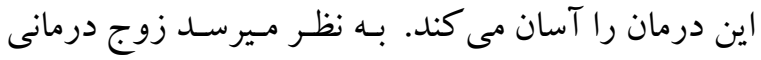
تر كيبى و زوج درمانى رفتارى تركيبى سبب مى شود زنان درباره خطا كارى و بيمان شكنى همسر مسئوليت بـيشترى بيذيرند و با بخشى از وجود خود روبرو شوند، كه به

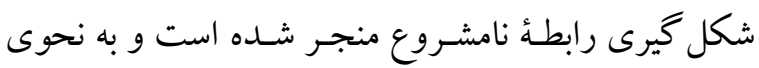
خود را تغيير دهند. هدف اين است كه هـر يكك از زوجين خود را براى وضعيتى كه در ايجاد رابطة نامشروع دخالت داشته اسـت، مسـؤل بدانند. زيرا انداختن بار مسئوليت تنها بر دوش يكى از طرفين تقريباً هيجگَاه در نقـض بيمـان زناشويى مصداق ندارد. مراجعان يـاد كرفتنــ كـه لازمة ايجاد و حفظ روابـط زناشـويى سـالم ايسن اسـت كـه طـرفين بـراى علاقـهنـدىهـا و و نيازمندىهاى يكديخر ارزش قائل شوند و سعى كنند در

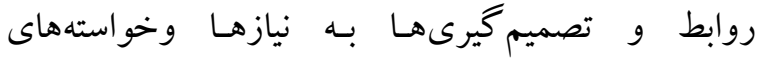
همسرشان توجه كنند. قبول مسئوليت و شناخت انتظارات متقابل، قدم اول در بهبود روابط آسيب ديده از خيانت 
Baucom DH, Pentel KZ, Gordon KC, Snyder DK. (2017). Anintegrative approach to treating infidelity in couples. In Foundations for Couples' Therapy (pp. 206-215). Routledge.

Connor KM, Davidson JR. (2003). Development of a new resilience scale: The Connor- Davidson resilience scale (CD-RISC). Depression and anxiety, 18(2), 76-82.

Delavar A, Naqshbandi S. (2019). Statistical Analysis in Psychology and Educational Sciences. Arasbaran publications. (In Persian)

Ebrahimi Moghadam H, Poori Mohammad M. (2015). Comparison of resilience and attachment styles betrayed spouses and normal spouses in Tehran, National Conference on Applied Research Educational Sciences and Psychology and Social Injuries. Tehran, Science Development and Promotion association and Basic Technologies and Center for Studies and Research. (In Persian)

Emadi Al-Hayari Sh, Atashpour SH. (2015). The effect of groupeducation based on an integrated selfanalysis approach to the productivity of women referring to cultural centers in Isfahan, the third scientific conference on educational sciences and psychology of social and cultural injuries in Iran, Qom. (In Persian)

Esfandiari D, Mohsenzadeh F, Kasai A, Asadpour I. (2019). The Effectiveness of Group Counseling with Rational, Emotional and Behavioral Approach (REBT) onForgiveness and Resilience of Women Affected by Marital Infidelity. Journal: psychological methods and models $»$ winter 2019 Issue 38 / ISC (28 pages - from 97 to 124). (In Persian)

Fincham FD, May RW. (2017). Infidelity in romantic relationships. Current Opinion in Psychology, 13, 70-74.

Fitypatrick J, Lafontaine MF. (2017). Attachment, trust, and satisfaction in relationships: Investigating actor, partner, and mediating effects. Pers Relationship, 24(3), 640-662.

Greenberg L, Warwar S, Malcolm W. (2010). Emotion-focused couples therapy and the facilitation of forgiveness. Journal of marital and Family Therapy, 36(1), $28-42$.

Gurman AS. (2008). The comparative study of couple therapy. In A. S-Gurman(Ed.), Clinical handbook of couple therapy (4th ed., pp. 1-30). New York: Guilford Press.

Haghayegh SA. (2020). The effect of treatment based on the acceptance and commitment therapy on infertility,

$$
\begin{aligned}
& \text { طولانىتر استفاده كرده، مرحله بيخيرى را در بزّوهش } \\
& \text { لحاظ كنند و همجينين اين بزَوهش را براى مردان آسيب } \\
& \text { ديده از خيانت همسر نيز تكرار كنند. } \\
& \text { سياسگز ارى } \\
& \text { نويسند گان بر خود لازم مىدانياند مراتب تشكر صميمانه }
\end{aligned}
$$

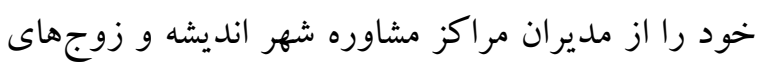

$$
\begin{aligned}
& \text { شركت كننده در اين يُوهش كه ما را در انجام و ارتقاء } \\
& \text { كيفى اين بزووهش يارى دادند، اعلام نمايند. }
\end{aligned}
$$

\section{References}

Aghagadi P, Golparvar M, Aghaei A, Khayatan F. (2019). The effect of forgiveness - based mindfulness therapy and emotion-based therapy on depression and resilience of women affected by breach of contract. Joumal of Community Health» Spring 2019No. 1.(InPersian)

Alarcon R, Cerezo MV, Hevilla S, Blanca MJ. (2020). Psychometric properties of the Connor-Davidson Resilience Scale in women with breast cancer. International Joumal of Clinical and Health Psychology, 20(1), 81-89.

Ali Babaei M, Khaleghipour Sh, Wahhabi Hamabadi Jalal. (2019). The Effectiveness of Integrated Loving Training with Positive Self-Expression on Hostility, Resilience and Positive Feeling of Spouse in Infidelity. Joumal :positive psychology» summer 2020 - Issue 18 (17 Pages - From 47 to 63). (In Persian)

Allison RT. (2017). Communication and parental infidelity: A qualitative analysis of how adult children cope in a topic-avoidant environment. Joumal of Divorce \& Remariage, 58(3), 175-193.

Arianfar N, Etemadi A. (2016). Comparison of the effectiveness of integrative and emotion- oriented couple therapy on marital intimacy of couples affected by infidelity. Journal of Consulting News and Research, Fall 2016No. 59.(In Persian)

Bacom DH, Snyder DK, Gordon KC. (2015). Getting past the affair (therapist guide). Translation (Moziri and Naderi). Tehran . Dear. (Date of publication in the original language, 2009). 
satisfaction of marriage and attitude toward to the infertility in sterile women. Shenakht Joumal of Psychology and Psychiatry. 2020; 7 (2): 13-25. (In Persian)

Haj Mohammad Reza N.(2016). Intercultural Comparison of Resilience Scale Componen Using Structural Validity, Psychometric Quarterly, No. 16. (In Persian)

Halchuk RE, Makinen JA, Johnson SM. (2010). Resolving attachment injuries in couples using emotionally focused therapy: A Three - Year followup. Journal of Couple \& Relationship Therapy, 9(1),31-47.

Jacobson NS, Christensen A. (1998). Acceptance and change in couple therapy: A therapist's guide to transforming relationships. New York:Norton.

Johnson SM, Brubacher LL. (2016). Emotionally focused couple therapy: Empiricism and art.

Kalai C. (2016). Integrative behavioral couple therapy for intercultural couples: helping couples navigate cultural differences. (InPersian)

Karimi J, Sudani M, Mehrabizadeh Honarmand M, Neisi A. (2013). Evaluation of the effectiveness of integrated couple therapy on reducing depression, posttraumatic stress symptoms and increasing forgiveness and intimate relationships afterinfidelity. Clinical and Counseling Psychology Research, 4 (2), 51-68. (In Persian)

Karimian N,Zarei A, Mohammadi K, Christensen A. (2016). Evaluation and Comparison of the Effectiveness of Combined Behavioral Couple Therapy (IBCT) and New Decision Making Treatment to Improve the Marital Disorder of Conflicting Couples in Sanandaj. Quarterly Joumal of Counseling and Psychotherapy Culture, Volume 7, Number 25. (In Persian)

Khojasteh Mehr R, Ahmadi Qozlujeh A, Sudani M, ShiraliNia K. (2015). The effectiveness of shortterm integrated marital counseling on emotional intimacy and marital quality of couples. Contemporary Psychology: Fall and Winter 2015, Volume 10, Number 2ina row 20; From page 29 to page 4. (In Persian)

Kordbache S, Arefi M. (2018). Assessing the quality of sexual intercourse in predicting marital infidelity of women in Isfahan, International Congress of Mental Health andPsychological Sciences, Tehran, Permanent Secretariat of the Conference. (InPersian)

Mairal JB. (2015). Integrative behavioral coupletherapy (IBCT) as a third-wave therapy. Psicothema, 27(1): 13-18.
Marin RA, Christensen A, Atkins DC. (2014). Infidelity and behavioral couple therapy: Relationship outcomes over 5 years following therapy. Couple and Family Psychology: Research and Practice, 3(1) 1.

Rokach A, Philibert-Lignieres G. (2015). Intimacy, loneliness and infidelity. The Open Psychology Joumal, 8(2), 71-78.

Sadeghi A. (2010). Comparison of the effectiveness of cognitive-behavioral therapy and the combination of pharmacotherapy and cognitive-behavioral therapy on resilience and stress of betrayed women. , M.Sc. Thesis, Payame Noor University, Central Tehran Branch. .(In Persian).

Snyder DK, Baucom DH, Gordon KC. (2007). Getting past the affair: A program to help you cope, heal, and move on - Together or apart. New York: Guilford Press.

Snyder DK, Balderrama - Durbin C. (2012). Integrative approaches to couple therapy: implications for clinical practice and research. Behavior therapy, 13-24.

Taheri E, Amiri M, Sadeghi Ordobadi A. (2016). Comparison of the effectiveness of integrated behavioral couple therapy and cognitive-behavioral couple therapy in betrayed women. Conference on Cognitive Behavioral Psychotherapy, 2016, Volume 4. (In Persian)

Tavares L, Aassve A. (2013). Psychological distress of marital and cohabitation breakups. Social Science Research, 42(6), 1599-1611.(In Persian)

Yu Y, Peng L, Chen L, Long L, Wang T. (2014). Resilienceand social support promote postraumatic growth of women with infertility: The mediating role of positive coping. Psychiatry Research, 215, 401-405. 